\title{
Achievements, challenges, priorities and needs to address the current tobacco epidemic in Latin America
}

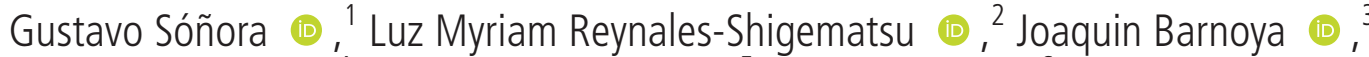 \\ Blanca Llorente (1), ${ }^{4}$ André Salem Szklo 다, James F Thrasher ${ }^{6}$
}

'Tobacco Control, International Union Against Tuberculosis and Lung Disease, Paris, France ${ }^{2}$ Departamento de Investigación sobre Tabaco, Centro de Investigación en Salud Poblacional, Instituto Nacional de Salud Pública, Cuernavaca, Morelos, Mexico

${ }^{3}$ Departamento de Investigacion, Unidad de Cirugia Cardiovascular, Guatemala, Guatemala

${ }^{4}$ Research Department, Fundación Anáas, Bogota, Colombia

${ }^{5}$ Population Research Unit, Instituto Nacional de Câncer,

Rio de Janeiro, Brazil

${ }^{6}$ Health Promotion, Education, and Behavior, School of Public Health, University of South Carolina, Columbia, South Carolina, USA

\section{Correspondence to}

Dr Gustavo Sóñora, Tobacco Control, International Union Against Tuberculosis and Lung Disease, Paris, France; gsonora@theunion.org

Received 20 August 2021 Accepted 22 November 2021

Check for updates

(c) Author(s) (or their employer(s)) 2022. No commercial re-use. See rights and permissions. Published by BMJ.

To cite: Sóñora G, ReynalesShigematsu LM, Barnoya J, et al. Tob Control

2022:31:138-141.

\section{INTRODUCTION}

In Latin America, about $80 \%$ of the population is protected by at least one of the six MPOWER measures ${ }^{1}$ promoted by the WHO Framework Convention for Tobacco Control (FCTC). ${ }^{11}$ Indeed, this region is among those with the highest levels of FCTC implementation: four countries have adopted at least four MPOWER measures at the highest implementation level and 16 countries have adopted between one and three measures. ${ }^{1}$ Progressive, sustained and synergistic implementation of FCTC measures has contributed to a regional reduction in smoking prevalence of more than $50 \%$ over 15 years. ${ }^{1}$

Brazil was the first Latin American country to implement all MPOWER measures, which was accompanied by a more than $75 \%$ reduction in smoking prevalence. ${ }^{1}$ Countries across the region were among the first to implement comprehensive smoke-free policies starting in $2006,{ }^{23}$ with South America becoming the first WHO sub-region where all countries are covered. ${ }^{4}$ The region also was relatively quick to adopt policies on prominent pictorial health warning labels (HWLs), ${ }^{5}$ with 13 countries now having pictorial HWLs that cover 50\% or more of the package. ${ }^{7}$ Uruguay was one of the first countries in the world to require plain packaging. ${ }^{6}$ In contrast, bans on advertising, promotion and sponsorship have been more unevenly adopted, with only Uruguay and Panama having comprehensive bans that include advertising at point of sale. ${ }^{7}$

With sustained commitment, most of the region should continue reducing the smoking prevalence to below $12.9 \%$ by $2025 .^{7}$ Despite these advances, tobacco use remains a leading preventable risk factors for disease, disability and premature death in Latin America, accounting for $10 \%$ of all deaths.

Smoking prevalence varies substantially across Latin America, ${ }^{8}$ ranging from $38.7 \%$ in Chile to 5\% in Panama, ${ }^{9}$ with heterogeneity across sub-regions. Smoking prevalence is lowest in the Andean region (Colombia, Bolivia, Ecuador and Peru) and highest in the southern cone (Argentina, Chile and Uruguay). ${ }^{10}$ It is generally more prevalent among vulnerable groups, including adolescents (particularly girls), young adults and, increasingly, the poor. ${ }^{7}$ These groups appear more sensitive to some tobacco control policies, particularly tobacco taxes, which is the most cost-effective of the MPOWER policies. Unfortunately, according to the 2021 WHO Report on the Global Tobacco Epidemic
2021, ${ }^{6}$ only Argentina, Chile and Brazil have levels of taxation that meet WHO standards.

\section{REGIONAL PRIORITIES AND KEY CHALLENGES}

The main priority for Latin America remains the full implementation of FCTC-recommended policies, which are based on the existing evidence of the most cost-effective tobacco control measures available. ${ }^{11}$ The FCTC's grounding in the right of all people to the highest standard of health provides a legal underpinning for global cooperation in tobacco control. Furthermore, this clear connection between tobacco control and human rights treaties has facilitated implementation because many Latin American countries enshrine health as a human right in their constitutions. ${ }^{12}$ Nevertheless, as in other parts of the world, novel nicotine products threaten to derail this progress.

In Latin America, electronic nicotine delivery systems (ENDS) first became available in $2007 . .^{13}$ Heated tobacco products (HTPs) have emerged more recently, with Colombia ${ }^{14}$ being the first country in the region where Philip Morris's "IQOS" became available in 2017 . Regulatory approaches to ENDS and HTPs differ across the region.

A few countries ban ENDS importation, sale and distribution, including in both large (Brazil,${ }^{15}$ Argentina, ${ }^{16}$ Mexico ${ }^{17}{ }^{29}$ ) and small markets (Panama, ${ }^{18}$ Uruguay, ${ }^{19}$ Venezuela ${ }^{20}$ ). Based on the Precautionary Principle, ${ }^{21} 22$ these prohibitions reflect the lack of conclusive evidence regarding ENDS harms and their effectiveness for cessation. Despite their legal prohibition, consumers in these countries are still able to access ENDS due to weak policy enforcement and the relatively large size of unregulated, informal economies. In Mexico, for example, the prevalence of ENDS use among adolescents is comparable to the USA, ${ }^{23-25}$ where e-cigarette regulations have only recently been adopted.

Bolivia, Paraguay, Costa Rica, Ecuador and Honduras regulate ENDS as a "tobacco product". ${ }^{26}$ This strategy is straightforward, although enforcement can be complex (eg, loopholes due to technical definitions of aerosol and/or smoke). On the other hand, Colombia, Peru, Guatemala, Dominican Republic and Nicaragua have no ENDS regulations. Chile is the only country in the region to regulate ENDS as pharmaceutical products because they contain nicotine. However, as of October 2021, no company has received authorisation 
to sell ENDS, due to the lack of clinical data to support their approval. $^{27}$

HTP marketing and sales are banned in Brazil, ${ }^{28}$ Mexico $^{2930}$ and Panama. ${ }^{31}$ For example, in Brazil, the National Health Surveillance Agency (ANVISA) Resolution banned "electronic smoking devices" in 2009, including both ENDS and HTPs. ${ }^{28}$ Companies must submit epidemiological and toxicological evidence to receive authorisation to import and sell any "electronic smoking device" intended for smoking cessation or as substitute for conventional cigarettes, regardless of nicotine content. The ANVISA resolution also banned advertising of both ENDS and HTPs in Brazil.

Bolivia, $^{32}$ Paraguay $^{33}$ and Uruguay $^{34}$ all specifically regulate HTPs as tobacco products. However, Argentina, Chile, Costa Rica, Colombia, Cuba, Ecuador, El Salvador, Guatemala, Honduras, Peru, Venezuela, Dominican Republic and Nicaragua have no HTP-specific regulations. For instance, the Colombian Tobacco Control Law (2009) $)^{35}$ bans advertising, promotion and sponsorship of tobacco and includes a nationwide smoking ban in workspaces and other public areas and 30\% size pictorial health warnings on tobacco products. Later legal interpretation has concluded that the wording of Tobacco Control Law encompasses HTPs since they are considered a tobacco product. However, PMI has side stepped these regulations by using different brand names for the "heatsticks" and heating device, which it markets freely by arguing that the heating device is not a tobacco product and therefore not covered by the regulations. To date, the consumer protection authority has not taken effective actions to combat this practice.

Since the U.S. Food and Drug Administration (FDA) authorised the marketing of PMI's HTP 'IQOS' as a modified exposure tobacco product in 2019, PMI has capitalised on this decision in its activities in Latin America. This includes mention of this decision in IQOS marketing strategies, as well as when lobbying decision-makers to lift prohibitions and weaken existing HTP regulations.

A key challenge for tobacco control in Latin America concerns flavoured tobacco products, including capsule cigarettes that are rapidly gaining global market share, particularly in Latin America. ${ }^{36}$ Flavoured cigarettes disguise the harshness of tobacco smoke, and, in the case of menthol, increase the reinforcing effects of nicotine on smoking behaviour. The variety of flavours in capsules has rapidly expanded beyond traditional menthol to include fruit and cocktail flavours. ${ }^{37}$ The industry has also introduced cigarettes with multiple capsules, each with different flavours, in a single stick ${ }^{38}$ as well as different flavours across sticks within a single pack. ${ }^{36}$ Flavour capsules appeal to adolescents, ${ }^{39}$ young adults, women and light smokers, ${ }^{40}$ potentially undermining MPOWER measures, as appears to have happened in Mexico. 384142

In 2012, Brazil became the first country worldwide to ban the sale of all flavoured tobacco. ${ }^{43}$ However, industry lawsuits effectively blocked implementation by claiming, among other arguments, that scientific knowledge about negative health effects from flavours is unclear and that the ban would increase illicit sales. ${ }^{44}$ Between 2012 and 2021, industry registration of flavoured tobacco products for legal sale in Brazil has more than tripled. ${ }^{45}$ Similarly, Chile faces political and economic challenges in its attempts to implement the 2015 law that banned menthol tobacco products. ${ }^{46}$ Where flavours are not banned, FCTC parties are encouraged to ban flavour descriptors and brand imagery (eg, graphic design, colour and fonts) to help reduce the appeal of flavoured tobacco for youth. However, as of October 2021, no Latin American country has banned additives and/ or flavours in tobacco products ${ }^{47}$ nor has removed packaging descriptors depicting flavours. ${ }^{6}$ Even where such bans have been introduced, industry has gone around them by using "concept descriptors" (eg, Havana Nights, Fusion Blast) instead of flavorspecific descriptors. ${ }^{48}$

Another key challenge for the region is tobacco taxationthe most cost-effective policy for reducing consumption. ${ }^{49}$ Yet taxes are the least implemented MPOWER measure across Latin America. ${ }^{50}$ The Tobacconomics Cigarette Tax Scorecard is a composite index that aggregates four elements of cigarette taxation (price, affordability, tax share and structure) to give countries an overall score out of five. ${ }^{50}$ Latin America had an average score of 2.62 in 2020, above the global average of 2.28. While many South American countries score well on the Scorecard, notable exceptions include Paraguay and Bolivia, which score 0.50 and 0.88 , respectively. Further tax increases are needed to make cigarettes less affordable

Recent tax reforms have been modest, as in Peru ${ }^{51}$ and Mexico, ${ }^{52}$ which updated the tobacco excise tariff between 2020 and 2021 to adjust for Consumer Price Index increases. In Brazil, despite a lack of inflationary adjustment since 2016/2017, the industry pressured the Ministry of Justice to consider reducing cigarette taxes to contain smuggling. ${ }^{53}$ The FCTC Protocol to Eliminate Illicit Trade in Tobacco Products aims to tackle illicit trade concerns, which are often raised when tax increases are proposed. ${ }^{54}$ Brazil, Costa Rica, Ecuador, Nicaragua, Panama and Uruguay became parties to the Protocol between 2013 and $2018^{55}$; however, no Latin American parties have ratified this initiative since then.

Another key challenge concerns taxing ENDS and HTPs in countries where they are legal. As in other countries, it is unclear how to design a tariff structure that reduces smoking while also considering the potential for incentivising use of potentially less harmful products among smokers who cannot otherwise quit, keeps youth from starting to use tobacco products and defines a tax base that can be effectively administered across the growing diversity of products. ${ }^{56}$ Colombia $^{57}$ and Peru $^{51}$ are the only countries that levy a tax on HTP "heatsticks", equivalent to the excise tax for cigarettes. However, the electronic component of the HTP is not taxed and the selective tax is not levied on ENDS. Key obstacles to ENDS taxation include the lack product standardisation (eg, some products report weight instead of volume), the ease of introducing new products without regulatory approvals and lack of institutional capacity to monitor the rapidly changing market. These problems are strongly linked to the absence of specific ENDS regulations in most Latin American countries.

Finally, providing access to and promoting the use of evidencebased smoking cessation support remains a challenge, as it depends to a great extent on the availability of human and financial resources. While some countries have dedicated resources for cessation, there is a need for comprehensive commitments by governmental and non-governmental organisations to address this critical issue. Governments urgently need to coordinate cessation strategies and develop national guidelines, ensure universal coverage of treatments that have proven to be costeffective, and guarantee access to and affordability of nicotine replacement therapies and behavioural support. Engagement with health professionals in training and treatment is critical, as is consideration of information technologies for delivering effective treatments that can be scaled up and disseminated widely. 5859 


\section{CONCLUSIONS}

Latin America has been relatively successful in implementing the key MPOWER measures of comprehensive smoke-free environments, prominent pictorial HWLs, and tobacco advertisement, promotion and sponsorship bans-their implementation has been accompanied by significant declines in tobacco use. Nevertheless, the region still faces a high disease and death burden attributable to tobacco, and implementation of some policies present challenges (eg, taxes, smoke-free environments ${ }^{260}$ ).

Several regulatory approaches to ENDS and HTPs have been implemented in the region, yet the public health impact of each approach is uncertain. As around the world, new industry marketing strategies aim to differentiate these products as less harmful than combustible tobacco products, and smokers and youth alike access and use these products even where they are banned.

The tobacco industry-vector of the tobacco epidemic-is changing, and legal frameworks must evolve to anticipate and address these changes. To accelerate the FCTC's positive public health impacts, adoption of a strong regulatory framework based on the FCTC and its Protocol is the critical starting point for regulating combustible tobacco and also HTPs and ENDS.

Funding In the writing of this manuscript, JB and JFT were supported by the Fogarty International Center of the National Institutes of Health under award number R01 TW010652.

Disclaimer The content is solely the responsibility of the authors and does not necessarily represent the official views of the National Institutes of Health.

Competing interests None declared.

Patient consent for publication Not applicable.

Provenance and peer review Commissioned; externally peer reviewed.

ORCID iDs

Gustavo Sóñora http://orcid.org/0000-0001-7826-4004

Luz Myriam Reynales-Shigematsu http://orcid.org/0000-0002-5350-0928

Joaquin Barnoya http://orcid.org/0000-0002-1731-479X

Blanca Llorente http://orcid.org/0000-0003-3350-1648

André Salem Szklo http://orcid.org/0000-0003-1903-6188

\section{REFERENCES}

1 WHO. WHO report on the Global Tobacco Epidemic: offer help to quit tobacco use. Geneva: World Health Organization, 2019. https://www.who.int/publications/i/item/ WHO-NMH-PND-2019.5

2 Thrasher JF, Nayeli Abad-Vivero E, Sebrié EM, et al. Tobacco smoke exposure in public places and workplaces after smoke-free policy implementation: a longitudinal analysis of smoker cohorts in Mexico and Uruguay. Health Policy Plan 2013;28:789-98.

3 Thrasher JF, Pérez-Hernández R, Swayampakala K, et al. Policy support, norms, and secondhand smoke exposure before and after implementation of a comprehensive smoke-free law in Mexico City. Am J Public Health 2010;100:1789-98.

4 PAHO/WHO. Sudamérica libre de humo de tabaco: Paraguay adopta medidas de protección para su población de la exposición al humo de tabaco. Available: https:// www.paho.org/es/noticias/5-1-2021-sudamerica-libre-humo-tabaco-paraguayadopta-medidas-proteccion-para-su-poblacion

5 Thrasher JF, Reynales-Shigematsu LM, Lazcano-Ponce E, eds. Salud pública y tabaquismo, Volumen II. "Advertencias sanitarias en América Latina y el Caribe". Public health \& tobacco, Volume 2: Warning labels in Latin America and the Caribbean. Cuernavaca, México: Instituto Nacional de Salud Pública, 2013.

6 WHO. WHO report on the global tobacco epidemic 2021: addressing new and emerging products. Geneva:World Health Organization, 2021. https://www.who.int/ publications/i/item/9789240032095

7 Pan American Health Organization. Report on tobacco control in the region of the Americas. Washington, DC: PAHO, 2018. https://iris.paho.org/handle/10665.2/49237

8 Centers for Disease Control and Prevention - CDC. The global tobacco surveillance system. GTSS, 2018. Available: https://www.cdc.gov/tobacco/global/gtss/index.htm

9 Instituto Conmemorativo Gorgas de Estudios de la Salud. Sistema de información de la Encuesta Nacional de Salud de Panamá (ENSPA) 2019-2021: Capítulo 9.

Salud mental, conductas adictivas $Y$ consumo de productos $O$ sustancias que causan dependencia. Panamá: : Departamento de Investigación y Evaluación de Tecnología Sanitaria, 2021.
10 GBD 2019 Tobacco Collaborators. Spatial, temporal, and demographic patterns in prevalence of smoking tobacco use and attributable disease burden in 204 countries and territories, 1990-2019: a systematic analysis from the Global Burden of Disease Study 2019. Lancet 2021;397:2337-2360.

11 World Health Organization. Framework convention for tobacco control. Geneva: World Health Organization, 2003.

12 Pan American Health Organization. Manual for developing tobacco control legislation in the region of the Americas. Washington, D.C. 20037, USA: Pan American Health Organization 525 Twenty- third Street, N.W, 2013.

13 Noel JK, Rees VW, Connolly GN. Electronic cigarettes: a new 'tobacco' industry? Tob Control 2011;20:81.

14 Philip Morris International (PMI). Sustainability report. Communication on progress 2016. United Nations global compact, 2016. Available: https://www.pmi.com/ resources/docs/default-source/pmi-sustainability/pmi_sustainability_report_2016.pdf [Accessed 19 Nov 2021].

15 Ministério da Saúde. Agência Nacional de Vigilância Sanitária -ANVISA. RESOLUÇÃO DA DIRETORIA COLEGIADA -RDC N²46, DE 28 DE AGOSTO DE2009, 2009. Available: http://antigo.anvisa.gov.br/documents/10181/2718376/RDC_46_2009_ COMP.pdf/2148a322-03ad-42c3-b5ba-718243bd1919 [Accessed 19 Nov 2021].

16 Ministerio de Salud. Secretaría de Políticas, Regulación e Institutos. Expediente NO 1-47-2409-11-1 del Registro de esta Administración Nacional de Alimentos, Medicamentos y Tecnología Médica, relacionado con cigarrillos electrónicos. Available: http://www.anmat.gov.ar/boletin_anmat/mayo_2011/Dispo_3226-11.pdf [Accessed 19 Nov 2021].

17 Secretaría de Salud (SSA). COFEPRIS. Comunicado conjunto. Por decreto presidencial, a partir de mañana queda prohibida la importación de cigarros electrónicos. Available: https://www.gob.mx/cofepris/prensa/comunicado-conjunto-por-decreto-presidenciala-partir-de-manana-queda-prohibida-la-importacion-de-cigarros-electronicos?idiom= es [Accessed 19 Nov 2021].

18 Gobierno de la República de Panamá. Gaceta Oficial Decreto Ejecutivo 1838 de, 2014. Available: https://www.gacetaoficial.gob.pa/pdfTemp/27678_A/GacetaNo_ 27678a_20141211.pdf [Accessed 19 Nov 2021].

19 Diario Oficial. Normativa y Avisos legales de Uruguay. Decreto N² 299/017 "Modificación del Art. 1 del Decreto 534/2009, relativo a la comercialización, importación, registro como marca o patente y publicidad de cualquier dispositivo electrónico para fumar. Available: https://www.impo.com.uy/bases/decretos/299-2017 [Accessed 19 Nov 2021].

20 Global Tobacco Control Law, Johns Hopkins, Institute for Global Tobacco Control - Country Laws Regulating E-Cigarettes - Countries. Available: https:// globaltobaccocontrol.org/en/policy-scan/e-cigarettes/countries?country=45 [Accessed 19 Nov 2021].

21 Green LW, Fielding JE, Brownson RC. The debate about electronic cigarettes: harm minimization or the precautionary principle. Annu Rev Public Health 2018:39:189-91.

22 International Union Against Tuberculosis and Lung Disease. The Union. Where bans are best, 2020. Available: https://theunion.org/sites/default/files/2020-08/TheUnion_ TobaccoControl_E-CigPaper_English_07.pdf

23 Zavala-Arciniega L, Lozano P, Kollath-Cattano C, et al. E-Cigarette use frequency and motivations among current users in middle school. Drug Alcohol Depend 2019;204:107585.

24 Zavala-Arciniega L, Reynales-Shigematsu LM, Lozano P, et al. Patterns of awareness and use of electronic cigarettes in Mexico, a middle-income country that bans them: results from a 2016 national survey. Prev Med 2018;116:211-8.

25 Barrientos-Gutierrez I, Lozano P, Arillo-Santillan E, et al. "Technophilia": a new risk factor for electronic cigarette use among early adolescents? Addict Behav 2019:91:193-200.

26 Global Tobacco Control Law, Johns Hopkins, Institute for Global Tobacco Control Country Laws Regulating E-Cigarettes. Available: https://globaltobaccocontrol.org/en/ policy-scan/e-cigarettes [Accessed 19 Nov 2021].

27 Biblioteca del Congreso Nacional de Chile. Ministerio de Salud. Resolución 2994 determina régimen de control a aplicar a los productos denominados genéricamente cigarrillos electrónicos, sus componentes y cualquier dispositivo similar que sea formulado sobre la base del principio activo de la nicotina. Available: https://www. bcn.cl/leychile/navegar?idNorma=1018562 [Accessed 19 Nov 2021].

28 Ministério da Saúde -MS. Agência Nacional de Vigilância Sanitária -ANVISA Este texto não substitui o(s) publicado(s) em Diário Oficial da União. RESOLUÇÃO DA DIRETORIA COLEGIADA -RDC N 46, DE 28 DE AGOSTO DE, 2009. Available: http://antigo.anvisa.gov.br/documents/10181/2718376/RDC_46_2009_COMP.pdf/ 2148a322-03ad-42c3-b5ba-718243bd1919 [Accessed 19 Nov 2021].

29 "Decreto por el que se modifica la Tarifa de la Ley de los Impuestos Generales de Importación y de Exportación. Diario Oficial. Available: http://www.dof.gob.mx/nota detalle.php?codigo $=5586899 \&$ fecha $=19 / 02 / 2020$ [Accessed 19 Nov 2021].

30 Diario Oficial de la Federación de México del 22 de Octubre de 2021. Available: https://www.dof.gob.mx/nota_detalle.php?codigo=5633607\&fecha=22/10/202 [Accessed 19 Nov 2021].

31 The Panamá Congress Approved a law (July 2021) at the time of this manuscript still to be enacted for the President of the Republic have not happened. Gobierno de la República de Panamá. Gaceta Oficial. Ministerio de Salud Resolución Nº 0953 (15/mayo/2018) POR La cual Se declara improcedente La comercialización de Los 
productos de tabaco calentados en La República de Panamá, Ya que no Se cuenta Con La evidencia científica que permita considerarlos inocuos 0 de beneficio para La salud de Los consumidores. Available: https://www.gacetaoficial.gob.pa/pdfTemp/ 28530_A/GacetaNo_28530a_20180522.pdf [Accessed 19 Nov 2021].

32 Law 1280. Diario Oficial, 2020. Available: http://www.silep.gob.bo/norma/15818/ley actualizada [Accessed 19 Nov 2021].

33 Law 5538, 2015. Available: https://www.mspbs.gov.py/dependencias/dnvs/adjunto/ 308cb1-LEY 55382015 QUEMODIFICAELRGIMENTRIBUTARIODELTABACO.pdf [Accessed 19 Nov 2021].

34 Presidencia de la República Oriental del Uruguay. La prohibición de la comercialización, importación, registro como marca, 0 patente Y publicidad de cualquier dispositivo electrónico para fumar dispuesta en El decreto No. 534/009 de 23 de noviembre de, 2009. Available: https://medios.presidencia.gub.uy/legal/2021/ decretos/03/cons_min_410.pdf [Accessed 19 Nov 2021].

35 Ley 1335, Congreso Nacional de la República Colombia. Ley 1335 Gaceta del Congreso 654, 2009. Available: http://svrpubindc.imprenta.gov.co/senado/view/ gestion/gacetaPublica.xhtml [Accessed 19 Nov 2021].

36 Moodie C, Thrasher JF, Cho YJ, et al. Flavour capsule cigarettes continue to experience strong global growth. Tob Control 2019;28:595-6.

37 Hoek J, Gendall P, Eckert C, et al. Young adult susceptible non-smokers' and smokers' responses to capsule cigarettes. Tob Control 2019;28:498-505.

38 Thrasher JF, Abad-Vivero EN, Moodie C, et al. Cigarette brands with flavour capsules in the filter: trends in use and brand perceptions among smokers in the USA, Mexico and Australia, 2012-2014. Tob Control 2016:25:275-83.

39 Barrientos-Gutierrez I, Islam F, Cho Y. Assessing cigarette packaging and labeling policy effects on early adolescents: results from a discrete choice experiment. Tob Control. In Press 2021;30:505-14.

40 Paraje G, Araya D, Drope J. The association between flavor capsule cigarette use and sociodemographic variables: evidence from Chile. PLoS One 2019;14:e0224217.

41 Zavala-Arciniega L, Reynales-Shigematsu LM, Levy DT, et al. Smoking trends in Mexico, 2002-2016: before and after the ratification of the WHO's Framework Convention on Tobacco Control. Tob Control 2020;29:687-91.

42 Gutiérrez-Torres DS, Saenz de Miera Juarez B, Reynales-Shigematsu LM, et al. Trends in cigarette brand preference among Mexican smokers: the rise of Pall Mall. Tob Control 2021:30:305-11.

43 Erinoso 0, Clegg Smith K, lacobelli M, et al. Global review of tobacco product flavour policies. Tob Control 2021;30:373-9.

44 ADVOCACIA-GERAL DA UNIÃO. AÇÃO DIRETA DE INCONSTITUCIONALIDADE N 4874. Available: https://actbr.org.br/uploads/arquivos/Parecer-AGU.PDF [Accessed 19 Nov 2021].

45 Ministério da Saúde -MS. Agência Nacional de Vigilância Sanitária—ANVISA. Consulta a registro. Available: https://www.gov.br/anvisa/pt-br/assuntos/tabaco/ consulta-a-registro [Accessed 19 Nov 2021].

46 WHO. Case studies for regulatory approaches to tobacco products: menthol in tobacco products. Geneva: World Health Organization, 2018. https://www.who.int/ docs/default-source/tobacco-hq/regulating-tobacco-products/who-nmh-pnd-18-1eng.pdf?sfvrsn=632b7704_2

47 Murray CJL, Aravkin AY, Zheng P, et al. Global burden of 87 risk factors in 204 countries and territories, 1990-2019: a systematic analysis for the global burden of disease study 2019. The Lancet 2020;396:1223-49.

48 Cohen JE, Welding K, Erinoso 0, et al. The flavor train: the nature and extent of flavored cigarettes in low- and middle-income countries. Nicotine Tob Res 2021:23:1936-41.

49 U.S. National Cancer Institute and World Health Organization. The economics of tobacco and tobacco control. National Cancer Institute tobacco control monograph 21. Bethesda, MD: U.S. Department of Health and Human Services, National Institutes of Health, National Cancer Institute; and Geneva, CH: World Health Organization, 2016

50 Chaloupka F, Drope J, Siu E. Tobacconomics Cigarette Tax Scorecard. 2nd edn Chicago, IL: Health Policy Center, Institute for Health Research and Policy, University of Illinois Chicago, 2021. www.tobacconomics.org

51 . Available: https://www.mef.gob.pe/es/normatividad-sp-9322/por-instrumento/ decretos-supremos/20291-decreto-supremo-n-181-2019-ef-1/file and https://www. gob.pe/institucion/mef/normas-legales/414612-034-2020-ef-15 [Accessed 19 Nov 2021].

52 Diario Oficial de la Federación de México del 25 de Noviembre de 2019. Available: http://www.diputados.gob.mx/LeyesBiblio/abro/lif_2020/LIF_2020_orig_25nov19.pdf [Accessed 19 Nov 2021].

53 Relatório Final do Grupo de Trabalho instituído pela Portaria n 263, de 23 de março de 2019. Available: https://www.inca.gov.br/publicacoes/relatorios/relatorio-finaldo-grupo-de-trabalho-instituido-pela-portaria-no-263-de-23-de [Accessed 19 Nov 2021].

54 Globalization and Health. Characteristics of illegal and legal cigarette packs sold in Guatemala. Available: https://globalizationandhealth.biomedcentral.com/articles/10 1186/s12992-016-0219-z [Accessed 19 Nov 2021].

55 FCTC. Parties to the protocol to eliminate illicit trade in tobacco products. Available: https://fctc.who.int/protocol/overview/parties [Accessed 19 Nov 2021].

56 WHO. WHO technical manual on tobacco tax policy and administration [Internet] World Health Organization, 2021. Available: https://www.who.int/publications/i/item/ 9789240019188

57 Subdirección de Fortalecimiento Institucional Territorial. Available: http://www. nuevalegislacion.com/files/susc/cdj/doct/mhcp_5560_18.pdf [Accessed 19 Nov 2021]

58 PAHO. Launch of Florence in Spanish: a digital health worker to help you quit tobacco. Available: https://www.paho.org/en/events/launch-florence-spanish-digital-healthworker-help-you-quit-tobacco

59 Costa Rica experience. Available: https://www.iafa.go.cr/noticias/709-costa-rica-esgalardonada-por-herramienta-online-para-dejar-de-fumar

60 Barnoya J, Monzon JC, Briz P, et al. Compliance to the smoke-free law in Guatemala 5-years after implementation. BMC Public Health 2016;16:318. 